\title{
ISLAMIC EDUCATION IN THE AL-QUR'AN AND SUNNAH (STUDY ABOUT THE MEANING OF EDUCATION AND IMPLICATION FOR EDUCATOR)
}

\author{
M. Imamuddin \\ Institut Agama Islam Negeri (LAIN) Bukittinggi \\ E-mail:m.imamuddin76@yaboo.co.id
}

\begin{abstract}
Andryadi
Institut Agama Islam (LAI) Yasni Bungo

E-mail:andryadi228@gmail.com

Zulmuqim

Universitas Islam Negeri (UIN) Imam Bonjol, Padang

E-mail:zulmuqim@yaboo.co.id

\section{Abstract}

Al-Qur'an and Sunnah Rasul are sources of Islamic teachings, thus Islamic education basically cannot be separated from the two sources. In both of sources, education is known by terms which meaning is related to Tarbiyah. In Qur'an, the meaning of education is often found in the surab with different meanings. The various meanings encouraged the researchers to analyze or examine them in order to recognize the educational terms in Quran and the implications for educators. The researchers used library research in collecting data and the results were analyzed based on deductive mindsets. The analysis shows that there are 12 terms which refers to education, such as Tarbiyah, Talm, Da'wah, tarkiyah, al-Tadris, al-tafaqquh, al-taaqqul, al-tadabbur, al-tazkirah, altafakkur, al-intidzar, and al-tigerizah. The implication of the meaning of education is that educators should possess and instill good qualities in themselves and their personalities. The ideal qualities that they should have are Tarbiyah, da'wah, talm, tazkiyah, al-Tadris, al-tafaqquh, al-taaqqul, al-tadabbur, al-tazkirah, altafakkeur, al-intidzar, and al-manizah as the terms mentioned in the Qur'an.
\end{abstract}

Keywords: Educators, Implications, Ideal Traits.

\section{Abstrak}

Al-Qur'an dan Sunnah Rasul merupakan sumber ajaran Islam, maka pendidikan Islam pada hakekatnya tidak boleh lepas dari kedua sumber itu. Dalam kedua sumber tersebut pendidikan lebih dikenal dengan istilah-istilah yang pengertiannya terkait dengan Tarbiyah. Seperti di Al-quran sendiri makna pendidikan banyak ditemukan pada suratsurat al-Quran yang mempunyai makna-makna yang berbeda. Dengan banyaknya maknamakna pendidikan dalam al-quran, penulis mencoba menganalisis atau mentelaah makna dari istilah-istilah pendidikan yang ada pada al-Quran dengan tujuan untuk mengetahui istilah-istilah pendidikan yang ada pada al-Quran serta menganalisis dampaknya terhadap pendidik. Peneliti menggunakan penelitian pustaka dalam mengumpulkan data-data dan hasilnya dianalisis berdasarkan pola pikir deduktif. Hasil analsis memperlihatkan bahwa terdapat 12 istilah yang mengacu pada Pendidikan, seperti Tarbiyah, talm, dakwah, tazkiyah, al-Tadris, al-tafaqquh, al-taaqqul, al-tadabbur, al-tazkirah, altafakkur, al-intidzar, dan al-mauizah. Implikasi dari makna pendidikan tersebut adalah pendidik hendaknya memiliki dan menanamkan sifat-sifat yang baik dalam diri dan kepribadiannya. Sifat-sifat ideal yang perlu dimiliki pendidik adalah Tarbiyah, dakwah, talm, tazkiyah, al-Tadris, altafaqquh, al-taaqqul, al-tadabbur, al-tazkirah, altafakkur, al-intidzar, dan al-mauizah yang merupakan istilah-istilah yang tertera dalam Al-Quran.

Kata Kunci: Pendidik, Implikasi, Sifat-sifat Ideal. 


\section{Introduction}

The essence of Islamic education is "the efforts of devout Muslim adults who consciously direct and guide the growth and development of the fitrah (basic abilities) of students through Islamic teachings towards the point of maximum growth and development. ${ }^{1}$

Al-Qur'an and Sunnah Rasul is a source of Islamic teachings, so Islamic education in essence cannot be separated from these two sources. In both sources education is better known by terms whose understanding is related to education, namely at-Tarbiyah.

Education or at-Tarbiyah according to Islam's view is part of human duty as the Khalifah of Allah on earth. Allah is Rabb al'Alamin also Rabb al-Nas. God is "who educates natural creatures and also educates humans. ${ }^{2}$ As the caliph of Allah, humans get the power and authority from God to carry out education for the natural world and humans, therefore in the context of this problem humans are responsible for carrying out such education.

Education theoretically contains the notion of feeding one's soul so that it gets spiritual satisfaction. ${ }^{3}$ Education to be directed towards growth in accordance with Islamic teachings, it must proceed through institutions and through the curricular system which is guided by Islamic sharia.

1 M. Arifin, Ilmu Pendidikan Islam Suatu Tinjauan Teoritis Dan Praktis Berdasarkan Pendekatan Interdisipliner (Jakarta: Bumi Aksara, 1991), h. 32.

2 Zuhairini, dkk.,Filsafat Pendidikan Islam (Jakarta: Bumi Aksara, 1995), h. 147

3 M. Arifin.

4 Nunu Burhanuddin, Konstruksi Pendidikan Integratif Menurut Hamka, JURNAL EDUCATIVE: Journal of Educational Studies Vo.1, No.1, Januari Juni 2016, DOI : 10.30983/educative.v1i1.119.

${ }^{5}$ Syaripudin Basyar, Pendidikan Islam Di Era Globalisasi: Antara Konsepsi Dan Aplikasi', ALIDARAH: JURNAL KEPENDIDIKAN ISLAM, 2018: doi.org/10.24042/alidarah.v8i1.3075.

6 Iswantir M, Gagasan dan Pemikiran Serta Praksis Pendidikan Islam di Indonesia (Studi Pemikiran dan praksis Pendidikan Islam Menurut Azyumardi Azra).
Islamic Sharia "will not be internalized and practiced if only taught, but must be educated through the educational process". ${ }^{4}$ Regarding education, in the Al-Quran has hinted that education issues are very important, if the Al-Quran is examined/explored in more depth then we will find some basic principles of education, which we can make inspiration to develop in order to build education quality. In the AlQuran the word education is mentioned with many terms. Therefore, the author tries to examine the meaning of the educational terms that are in the Al-Quran and its implications for educators.

\section{Research Methodology}

This research belongs to the study of literature or library research. ${ }^{5}$ Library research is a study by examining various literatures related to Islamic education, especially study about the meaning of education and implication for educator. Critically review or review sources of knowledge, ideas, or findings contained in the body of academic oriented literature. ${ }^{6} \mathrm{In}$ finding reading sources, a researcher must be selective because not all can be used as data sources. $^{78}$

Data collection is collected from relevant sources, such as from books, journals, proceding and other relevant sources. Data obtained from relevant references, analyzed in deductive thinking is a way of thinking from the general to conclude to be specific. ${ }^{9}$ The more findings

JURNAL EDUCATIVE: Journal of Educational Studies Vol 2, No 2, Juli - Desember 2017, DOI : 10.30983 /educative.v2i2.471.

7 Alfurqan dan Harmonedi, Pandangan Islam Terbadap Manusia : Terminologi Manusia dan Konsep Fitrah serta Implikasinya dengan Pendidikan. JURNAL EDUCATIVE: Journal of Educational Studies Vol 2, No 2, Juli - Desember 2017, DOI : 10.30983/educative.v2i2.468.

8 Isnaniah and M. Imamuddin, 'Students' Understanding of Mathematical Concepts Using Manipulative Learning Media in Elementary Schools', in Journal of Physics: Conference Series, 2020: doi.org/10.1088/1742-6596/1471/1/012050.

9 Mafidin, Studi Literatur Tentang Peran Muhammadiyah Dalam Mengembangkan Pendidikan Islam Di Indonesia, Jurnal Tarbawi, 1.1 (2012), 43-53. 
that are similar, equivalent or equal will make it easier for researchers to draw conclusions.

\section{Results and Discussion The Meaning of Education}

Education is a form of human interaction. ${ }^{10}$ Education is a planned process in developing all the potentials of humans to have intelligence, morals and spirituality and life skill. In Law No. 20 of 2003 concerning the National Education System mentioned education is a conscious and planned effort to create an atmosphere of learning and learning process so that students actively develop their potential to have the spiritual power of diversity, selfcontrol, personality, intelligence, noble character and the skills needed by them, society, nation and state. ${ }^{11}$

Education is a process for humans to be able to run lives and fulfill their life goals more effectively and efficiently. Education is more than mere teaching, but education is a transformation of values and the formation of awareness and personality of students in addition to transfer of knowledge and expertise. ${ }^{12}$ Education is the most strategic effort to elevate human dignity as the most noblest creatures. ${ }^{13}$

Explanations regarding education in Islamic education are found in the $\mathrm{Al}$ Quran:

\section{a. Tarbiyah}

In the Al-Quran there is no word at-Tarbiyah, but Ahmad Tafsir explains that the word Tarbiyah comes from three words: touch, rabbi, and rabba. ${ }^{14}$ The word Rab-Yarb-Tarbiyatan with the meaning of your names means to grow and grow big. The word RabiyaYarb with wazan khafia-yakhfa means rising, becoming big / mature, growing and developing. Thus Tarbiyah means an effort to grow and mature students both physically, socially, and spiritually. Katarabba-yarubbu with the meaning of aslahahu (improve it), Tawalla ammarahu (take care of the case, take responsibility for it), sasah (train it, regulate, govern), qama alayhi (guarding, observing, helping) and raahu (caring and leading) ${ }^{15}$ According to al-Raghib al-Asfahaniy $(502 \mathrm{H} / 1108 \mathrm{M})$ is growing/developing something step by step until it reaches a perfect limit. ${ }^{16}$ In addition, the word rabb which is the root word of the word Tarbiyah also means a source that provides knowledge, and can also mean something given to someone, such as someone who adorns himself with knowledge. ${ }^{17}$ Furthermore, the word rabb is attributed to al-rabb Louis Maluf, interpreting al-Rabb with the lord, owner, repairing, caring, adding, collecting, and beautifying. ${ }^{18}$ Whereas alQurthubi (486H-576H) gives the meaning of al-rabb with the owner, master, the almighty fix, the almighty regulator, the almighty add, and the almighty to fulfill. ${ }^{19}$ Imam Fakhruddin al-

15 Maragustam, Mencetak Pembelajar Menjadi Insan Paripurna, (Yokyakarta: Nuha Litera, 2010), h. 21

16 Abudin Nata, Pendidikan Dalam Prespektif Al-quran, (Jakarta: UIN Jakarta Press, 2005), h. 90.

17 Abudin Nata

${ }^{18}$ Louis Maluf, al-Munjid fi al-Lughah wa alAlam, (Beirut: Dr al- Masyriq, 1984), Cet. XXVII, h . 243-244.

${ }^{19} \mathrm{Ab}$ Abdillh Muhammad bin Ahmad al-Anr al-Qurthub, al-Jmi li-Abkmi al-Qurn, Jilid I (t.d), h, 136-137. 
Razi (544H / 1210M) argues that al-rabb is a word similar to al-Tarbiyah which means al-tanmiyah (growth and development). ${ }^{20}$

Thus Tarbiyah means efforts to maintain, nurture, care for, improve, and regulate the lives of students, so that they can survive more in their lives. Rabba said with all its derivatives mentioned in the Qur'an 981 times. ${ }^{21}$

Based on the etymological understanding of Tarbiyah above, the three Tarbiyah originals are: touch, rabbi, and touch. The word Tarbiyah has quite broad meanings, namely: 1) Al-namayanamu, which means increasing, developing, and growing big little by little.2) Aslahahu which means improving students if the development process deviates from Islamic values. 3) Tawalla ammarahu which means dealing with the case of the learner, being responsible for it and training it.4) Raahu which means maintaining and leading in accordance with their potential and character.5) Al-tansyiah which means to educate, nurture, in the sense of material (physical) and immaterial (heart, mind, soul, and feelings), all of which are educational activities. ${ }^{22}$

From the above view, it provides an understanding that the term alTarbiyah covers all aspects of education, namely cognitive, affective, and psychomotor aspects. Both those covering the physical aspects, as well as the spiritual aspects are harmonious, so that humanity will develop themselves. Syed Naquib Al-Attas (1931 AD), alTarbiyah contains the meaning of educating, maintaining and maintaining all of His creations including humans, animals and plants. ${ }^{23}$ While Samsul Nizar explained the word al-Tarbiyah containing the meaning of caring, responsible, feeding, developing, maintaining, growing, growing and producing both covering both physical and spiritual aspects. ${ }^{24}$

From the translation of the content of the meaning implied by the term $\mathrm{Al}$ Tarbiyah, it means that the education offered must be process, planned, systematic, have the target to be achieved, there are executors (educators), and have certain theories. If so, the message contained in the term Tarbiyah is quite suitable to be used in referring to the notion of Islamic education because it covers all the cognitive, affective, psychomotor domains.

\section{b. Ta'lim}

The second word that has a relationship with aspects of education and teaching is the word talm. The word talm, is Mashdar isim from the word allama-yuallimu which means to teach, give a sign, educate, And words that contain the meaning of teaching are repeated 42 times for the understanding which generally teaches, including the following:

1. Teaching the book of Al-Qur'an, wisdom, and the gospel, as stated in Surah Al-Maidah verse 110 and Surah Al-Baqarah verse 151 which means as follows: (Remember), when Allah says: "Isa, son of Mary, remember my blessings to you and your mother when I strengthen you with Ruhul qudus. You can talk to humans while still in the cradle and when they are adults; and (remember) in when I taught you to write, wisdom, the Torah and the Gospel, and (remember also) when you formed

20 Imm Fakhruddn al-Rzi, Tafsr al-Kabr, (Beirut: Dar al-Kutub al-Ilmiyah, 1990), Jilid X. Juz XX, Cet.ke-I. h. 153.

${ }^{21}$ Muhammad Zaki Muhammad Khadr, Mujam Kalimat al-Quran al-Karim, Juz 12, 2005, h. 3.

22 Maragustam, Mencetak Pembelajar Menjadi Insan Paripurna, (Yokyakarta: Nuha Litera2010), h. 22.
23 Jalaluddin, Teologi Pendidikan, (Jakarta: PT. RajaGrafindo Persada, 2003), 115.

24 Samsul Nizar, Pengantar Dasar-Dasar Pemikiran Pendidikan Islam,(Jakarta: Gaya MediaPratama, 2001), h. 87. 
from the ground (a form) in the form of a bird with my permission, then you blew on it, then the shape became a bird (the real thing) with permission And, (remember) when you heal the blind from the womb of the mother and the one with the hairpiece with my permission, and (remember) when you bring the dead out of the grave (come alive) with my permission, and (remember) when I prevented the Children of Israel (from wanting to kill you) when you presented them with clear statements, then the disbelievers among them said: "This is nothing but magic real ". (Surat alMaidah: 110). As (we have perfected our grace to you) We have sent you the Apostles among you who read our verses to you and sanctified you and taught you the Book and the Wisdom, and taught you what you do not know. (Surat al-Baqarah: 151).

2. To state the angel's recognition that his knowledge is only taught by Allah SWT to him, for example in Surah AlBaqarah: 32 which means: They answered: "You are pure, you know nothing, except that which you have taught us; surely you are the Almighty, knowing the Wise (QS Al-Baqarah: 32).

3. Describe the expression of the Prophet Joseph who obtained the post of king and the ability to make dreams come true. Located in the Surah Yusuf: 101 which means: My Lord, verily You have given me part of the kingdom and have taught me as part of the dream ta'bir. Creator of the heavens and the earth. You are the protector of the world and in the hereafter, remember me in the State of Islam and join me with the righteous. (Surah Yusuf: 101).

4. To illustrate the power of Allah SWT in giving teachings to the Prophet in the form of teachings that are the shortest in the book, alhikmah, and everything that is not yet known by the Prophet, as contained in the letter annisa verse 113 which means: If it were not for the grace of God and His mercy on you, surely a group of them had a strong desire to mislead you. But they were not misleading but themselves, and they could not harm you in the slightest. And (also because) Allah has revealed your book and Wisdom, and has taught you what you did not know. and is a great gift from God upon you. (Surat an-Nisa: 113).

5. To show a remembrance that was taught by Allah SWT, as contained in Surah Al-Baqarah verse 239 which means: If you are in a state of fear (danger), then pray while walking or driving. Then if you are safe, then say Allah (Salat), as Allah has taught you what you do not know yet. (Surat alBaqarah: 239).

6. To explain the teachings given to the Prophet Muhammad SAW as contained in the letter Yasin verse 69 which means:

And We do not teach poetry to him (Muhammad) and poetry is not appropriate for him. The AlQuran is nothing but a lesson and a book that gives light. (Surat Yasin: 69).

Based on the verses above, there are several aspects related to the term altalim, namely: first, the aspect of the doer or implementer of teaching in this case is Allah SWT, and sometimes there are others such as scribes and sorcerers, second, aspects of his work that in this case the work of teaching or providing knowledge, third, aspects taught, namely in the form of the book of the Torah, the Gospel, the Qur'an, the takwil of dreams, al-hikmah, and knowledge directly from God (Laduni science), seeta other knowledge in the form of guidance, fourth, the aspect of being subjected to, that is, those who are given that 
knowledge, in this case, consisting of the prophets, and humanity in general. ${ }^{25}$

Based on the description above, it can be concluded that talm is a learning process that is carried out by a teacher to his students routinely. The learning process has an influence on the intellectual change of students. The intellectual change does not stop at mastering the material taught by teachers, but also affects the learning behavior of students, from lazy to diligent, or from non-creative to creative. Based on this conclusion, the word talm has an understanding which is narrower than Tarbiyah. Because it refers more to the educational aspects of science.

\section{c. Tazkiyah}

The concept of education in the Qur'an is obtained through the interpretation of the word Tazkiyah. The word tazkiyah comes from the word zakk-yuzakk which means that many of them are developing, growing, increasing. Also can mean purifying, cleaning and repairing. ${ }^{26}$ The concept of education is also obtained in the Qur'an through the interpretation of the word tazkiyah. Namely, means the process of sanctification through divine guidance. The word tazkiyah which means to grow and develop based on the blessing of Allah. This meaning can be used in both worldly and ukhrawi contexts. So that the word zakat in Islamic teachings means something that is issued by humans taken from the rights of God, given to the poor, both intentions to expect barakat to cleanse the soul, to open the chest and to get a blessing in doing good. Said tazkiyah is contained in the Al-Quran various derivations repeated 69 times. The word tazkiyah with its derivation comes from the work of zak, zakk and yuzakky which is contextualized by the nafs being repeated 21 times and 4 times in the form of isaf tafdhl which is attributed to humans. Humans are actually given by Allah SWT. The potential to purify their souls. This means that the potential is the nature that Allah SWT. Give it to everyone who wants to develop his potential to be clean and his soul to be more holy. Allah SW'T. Said in surah al-A'la, which means: Surely, it is fortunate that those who clean themselves (with faith) (QS al-A'la 14).

The explanation of the above verse, shows the meaning of tazkiyah is contextualized with education, so that the word education taken from the meaning of tazkiyah is more directed at the purpose of purifying the soul. Because with a clean soul, it will produce good deeds. Conversely, if the soul is dirty, will result in bad deeds. From this concept, it can be understood that in education there is a process of growth or self-development of students or social units so that they become pure and clean according to their nature. ${ }^{27}$

\section{d. Tadris}

Tadris has the meaning of remaining traces left, and the remainder of the ex requires a serious effort because the lessons are explained in a complete way. ${ }^{28}$ Among the verses of the Qur'an that uses the word al-Tadris is the Surah al-Anam which means: Thus, We repeat the verses of Thursday effort (those who believe receive guidance) and efforts for the polytheists to say:

"You have learned those verses (from the People of the Book)", and so that you explain the Qur'an to those who know (Surat al-Anam: 105)

This definition gives the meaning that al-tadris places more emphasis on the learning process, while the subject of al-tadris is God and the nabis while the
25 Abuddin Nata,..., h. 95.
26 Abuddin Nata,..., h. 115
27 Muhaimin, Nuansa Baru Pendidikan Islam; Mengurai Benang Kusut Dunia Pendidikan, (Jakarta: PT. Raja Grafindo Persada, 2006), h. 11.

28 Abudin Nata, ..., h. 99. 
target object is mankind, and the teaching material is the books.

\section{e. At-Tafaquh}

The word at-tafaquh comes from the word tafaqqaha-yatafaqqahutafaqquhan which means to study. The word tafaqquh comes from the word faqiha or alfiqh which means to relate to unseen knowledge (rational) with visible knowledge. ${ }^{29}$ The word tafaqquh in the Al-Quran is repeated 20 times. Among them are in the letter as follows:

1) Used for the meaning of understanding, for example in the letter An-Nisa: 78 which means:

Wherever you are, death will get you, Even though you are in a strong fortress, and if they get good, they say: "This is from the side of God", and if they are afflicted by something disaster they say: "This (coming) from the side ye (Muhammad) ". Say:" Everything (coming) from the sight of Allah". Then why those people (hypocrites) Almost did not understand the slightest conversation? (Q.S An-Nisa: 78).

2) Used for the meaning of knowing as contained in Surah Al-Anam: 98 and At-Taubah: 87 which means: And $\mathrm{He}$ created you from yourself, Then (for you) there is a permanent place and a place of storage. Truly We have explained the signs of Our greatness to those who know (Q. Al-Anam: 98).

They are willing to be with people who are not at war, and their hearts have been locked to death. So they don't know (happiness of faith and jihad). (Q.S.At-Taubah: 87).

3) Used for the meaning of understanding, as found in Sura alanfal: 70 and At-Taubah: 127 which means:
O Prophet, Say to the captives who are in your hands: "If Allah knows goodness in your heart, He will surely give you better than what has been taken from you and He will forgive you". and Allah is Forgiving, Most Merciful. (Q.S Al-anfal: 70). And when one letter is sent down, some of them look at the others (while saying): "Has anyone of (the Muslims) seen you?" after that they left. God has turned their hearts because they are a people who do not understand. (Q. At-Taubah: 127).

4) Used for the meaning of deepening, as found in the taubah-Taubah: 122 which means:

It is not proper for the believers to go all out (the hardships of the war). Why not go away from each group among them a number of people to deepen their knowledge of religion and to warn their people if they have returned to him, so that they can guard him. (Surat at-Tawbah: 122)

Based on the information above, it can be concluded that the word al-Tafaqqahun implies understanding, knowing, understanding and deepening. These understandings are closely related to the activities of gaining knowledge, experience, skills, and so on which are an integral part of learning activities contained in educational activities.

\section{f. Al-Taaqqul}

The word al-taaqqul comes from the word al-aql which means the power that is provided to receive knowledge and also means that every knowledge that can be utilized by humans through a force

29 Abudin Nata. 
called as common sense. ${ }^{30}$ Furthermore Raghib al-Ashafani said that the original meaning of the aqal word was to hold or maintain or bind. ${ }^{31}$

Based on the language understanding above, it can be understood that mind is active rather than passive, because reason relates to the work of acquiring knowledge, maintaining and maintaining memory of knowledge, and also means protecting people from the possibility of losing consciousness by doing something that is out of their control.

Humans as agents and objects of education through the use of reason can achieve goodness and success in life through education. Qur'an always encourages humans to use their minds to observe, examine the universe. This can be seen in Surat Ali Imron verses 190191 which means:

Verily in the creation of the sky and the earth, and the alternation of night and day there are signs for intelligent people. (ie) those who remember Allah while standing or sitting or in a lying down and they are thinking about the creation of heaven and earth (while saying): "O our Lord, Thou hast not created this in vain. hell. (AlImron: 190-191)

In the above verse, it appears that a person of understanding (Ulul Albab) is a person who does and combines (combines) between tadzakkur (zikir) and Tafakkur (thought) or otherwise. When he thinks, researches or examines nature as soon as dhikr appears and when he does dhikr comes his thinking. ${ }^{32}$ By doing both of these things will reach the wisdom of knowing, understanding and experiencing that behind the natural phenomena and everything that is in it shows the existence of the Creator of Allah SWT. Muhammad Abduh (1849 AD-1905M), stated that by contemplating the creation of heaven and earth, the shift of day and night would bring people to witness the Oneness of God, namely the rules he made and the gifts and various benefits contained there in. ${ }^{33}$ It shows the logical function as a tool to remember, think and reflect.

Happiness can be seen from the emergence of a variety of human findings in science and technology which in essence is a generalization or theorization of the symptoms and laws contained in the universe. ${ }^{34}$ This situation can also lead humans to be grateful and believe that all God's creations turned out to be very beneficial and not in vain.

\section{g. Al-Tadabbur}

The word Tadabbur comes from the word dubura which means the opposite of the word accept (khilafalqubul) and means to turn away. ${ }^{35}$ From the word Dubbura it was formed into the word dabbara which is the meaning of altadbir which means thinking after the event. ${ }^{36}$ From the word also comes the word tadabaru which means back to back or overtaking with the aim to rival unhealthy. The word al-tadabbur is also allied with the word yudabbiru which in the Qur'an is repeated 21 times. The word yudabbiru sometimes means creating, organizing, thinking and pondering. ${ }^{37}$ As contained in the letter Jonah: 3 and Annisa: 82 which means:

Verily, your Lord is the God who created the heavens and the earth in six periods, then $\mathrm{He}$ dwells on the 'Arsy to arrange all matters.
30 Al-Raghib al-Ashafahaniy, Mujam Murfadat Alfadz al-Quran, (Beirut: Dar al-Fikr, t.t.), h. 354.

31 Al-Raghib al-Ashafahaniy.

${ }^{32}$ Kadar M. Yusuf, Tafsir Tarbawi: Pesan-Pesan Al-Qur-an tentang Pendidikan, Cet-ke-I (Jakarta: Amzah, 2013), h. 85.
33 Ahmad Musthafa Al-Maraghiy, Tafsir AlMaraghiy, juz XXVIII, (semarang: CV Toha Putra, 1989), h. 26.

34 Ahmad Musthafa Al-Maraghiy.

${ }^{35} \mathrm{Al}$ Raghib al ashfahahiy, ..., h. 166.

36 Abuddin Nata,..., h. 113

37 Abuddin Nata 
(Essence) Such is Allah, your Lord, so worship Him. Then are you not taking lessons? (Qur'an, Jonah: 3).

So do they not pay attention to the Qur'an? If the Al-Quran is not from Allah's side, surely they will get a lot of contradiction in it. (Q. An-nisa: 82).

In the above verse, it is seen that the word Yudabbiru or yatadabbaruber means regulating, paying attention, pondering, thinking and so on. All of these activities utilize the potential of reason and all the abilities of the five senses, as well as other inner potentials. With these activities will be obtained wisdom, lessons, values and others, which ultimately arrive at the blessings of Allah SWT.These lessons, wisdom, and values come behind or later, after the reflection, thought, and attention. thus, through the activities of tadabbur or yatadabbara all events will be given that transcendental meaning that connects man and his creator, which in turn, he will become a person who always remembers the power of Allah SWT, then be careful and grateful to him.

\section{h. Al-Tazkirah}

The word al-tazkirah comes from the word al-dzikr which means a mental condition that allows humans to memorize something that is taught to them in the form of knowledge. Thus the word al-dhikr is the same as al-hafidfz which means to memorize with a difference, that memorizing refers to something that is visible, and sometimes is intended to present something to the heart or speech. and oral dhikr. ${ }^{38}$ In alquran the word al-tazkirah is repeated 9 times, as found in surah thaha: 2-3 and Al-waqiah: 73 which means:

We do not send this Qur'an to you so that you will be troubled; but as a warning to those who are afraid (of Allah), (Q.S. Thaha: 2-3)
We made the fire for warnings and useful materials for travelers in the desert. (Surat al-Waqiah: 73)

From the above verse, it is seen that the word tazkirah means a warning so that people do not let their guard down, and also so that with this warning someone can catch the message contained therein. Furthermore, from this tazkirah words also develop yatazakkaru words as in the Ar-rad verse: 19 and Shaad: 29 which means:

Does anyone know that what is revealed to you from your Lord is the same as a blind person? only intelligent people can take lessons, (Q.S Ar-rad: 19).

this is a book that We send down to you full of blessings so that they pay attention to His verses and learn from those who have thoughts. (Q.SShaad: 29).

From the verses above, it is known that the word yatazakkaru means to pay attention or to ponder, the results of this reflection and attention are lessons, in the form of positive values that are useful for human life in the world and the hereafter. Furthermore, from that word also arises the word al-dhikr which is repeated 52 times in the Al-Quran, as found in Surah Ar-Rad: 28, An-Nahl: 43, and Al-Hijr: 9 which means:

(ie) believers and their hearts are at peace in the remembrance of Allah. Remember, only by remembrance of Allah does the heart become at peace. (Q.S Ar-Rad: 28).

And We did not send before you, except men who We gave revelations to them: So ask someone who has knowledge if you do not know, (Q.S An-Nahl: 43).

Verily We are the one who revealed the Qur'an, and Indeed, We really take care of it, (Q.SAl-Hijr: 9).

\footnotetext{
38 Al-Raghib al-Ashafahaniy,..., h. 166.
} 
From the above verse, it can be understood that the word al-dhikr means remembering, knowing and al-quran. The activity of remembering is closely related to digesting, recording, storing memory which results in knowledge stored in memory. Such knowledge comes from Allah SWT stored in alQuran. Thus al-Quran is a source of knowledge, that is knowledge that comes directly from Allah, and on that basis alquran is called al-Dhikr. Thus, the word al-Tazkirah means warning, paying attention, pondering, remember and know, this activity is closely related to education and teaching activities.

\section{i. Al-Tafakkur}

The word al-Tafakkur comes from fakara or al-fikrah. According to alRaghib al-Ashfahaniy that thinking is a power that can be used to gain knowledge until the knowledge is known. While al-Tafakkur is the process of using that thought by using the power of reason. This, only happens to humans and not animals. It does not happen except in something that allows the image can be generated in the heart. ${ }^{39} \mathrm{In}$ the Al-Quran there is the word tafakkaru with various meanings and contexts, as found in Surah Al-Baqarah: 219 and AlA'raf: 176 which means:

They ask you about khamar and gambling. Say: "In both of them there is a great sin and some benefits for humans, but both sins outweigh the benefits". and they ask you what they spend. Say: "more than necessary." Thus Allah explains His verses to you so that you think, (Q.S Al-Baqarah: 219).

And if We will, Indeed, we elevate (the degree) with those verses, but $\mathrm{He}$ is inclined to the world and obeys his lust, then his parable like your dog if you obliterate his tongue and if you let him stretch out his tongue (also). That is the parable of those who reject our verses. Then tell them (stories) so they can think. (Q.S Al-A'raf: 176).

In the above verse, it can be understood that the word tafakkaru is associated with thinking activities whose objects are diverse, namely about various prohibitions of god such as liquor, and gambling: past events, and revelations revealed by Allah SWT. Thus, the word tafakkaru relates to the activity of capturing messages of teachings or wisdom contained in various decisions of Allah SWT. The ability to capture messages or wisdom is closely related to educational and learning activities.

\section{j. Al-Intidzar}

The word al-Intidzar comes from the word nadzara which means to flip over the head or eye of the heart to find something that thinks about it, and sometimes it is also used to mean contemplating and conducting experiments, and sometimes it is used to mean the knowledge generated after an experiment, and that is what follows called thought. ${ }^{40}$

This includes thinking and having alternative perspectives and reviewing ideas and work plans that have been made from sharing perspectives in order to anticipate a better future. ${ }^{41}$ The word al-Intidzar derived from the word nadzara in the Al-Quran is repeated 150 times. As contained in the Surah AlImran: 137 and al-A'nam: 11 which means:

Indeed, it has passed before you are the sunnah of the sunnah of Allah; therefore walk ye on the face of the earth and pay attention to the

39 Al-Raghib al-Ashafahaniy, ..., h. 398.

40 Al-Raghib al-Ashafahaniy,..., h. 518-519.

${ }^{41}$ Muahaimin, Rekonstruksi Pendidikan Islam :

Dari paradigma Pengembangan, Manjemen Kelembagaan,
Kurikulum bingga Strategi Pembelajaran, (Jakarta: RajaGrafindo Persada, 2009) ,h. 75. 
consequences of those who deny (the apostles). (Q.S Al-Imran: 137).

Say: "Walk on the face of the earth, then pay attention to how the end of the deniers." (Surat al-A'nam: 11).

In the above verse, it is seen that the word Undzuru is meant to pay attention to observing, categorizing, the difference, in the sense of knowing, finding elements of comparing, observing, understanding, similarities and analyzing, concluding, and verifying. The things that become the object of these activities will give birth to various kinds of knowledge according to the focus in making observations, observations, observations of various other things, events such as the past producing historical knowledge, observing the process of the occurrence of rain producing materialology and geophysics, analysis of various processes of growth and development of flora which then produce peratanian science, and analysis of the human creation process that gave birth to biology. Thus, the term al-intidzar is closely related to the process of education and teaching that is related to the process of research on social sciences and exact sciences with a wide variety of branches.

\section{k. Al-Mauidzah}

The word al-Mauidzah is derived from the word al-wadz which means sermon, advice, speech, and after becoming al-Mauidzah plural mawaidz means teaching or advice. ${ }^{42}$ Furthermore, according to al-Raghib al-Ashafahaniy alMauidzah means a warning or prevention accompanied by scare, then according to al-Khalil al-Wadzu means a warning to do good that can thrill the heart. ${ }^{43}$ Kataalwadz contained in the Al-Quran in various variations repeated 28 times, for example in the letter Lukman verse 13 and Jonah verse 57 which means:
And (remember) when Luqman said to his son, when he gave a lesson to him: "my son,, do not associate Allah, Truly associating (Allah) is truly a great tyranny" (Q.S Lukman: 13).

O people, verily you have come to learn from your Lord and healer for the diseases that are in the bosom and guidance and mercy for those who believe. (Q.Sunun: 57).

In the above verse, it is seen that the word al-waaz means teaching, advice, warning in the sense of prevention to frighten and a warning to do good that can thrill the heart. Thus, the term alMauidzah is closely related to the process of education and teaching.

Based on the eleven terms that are described relating to education contain a very broad meaning which as a whole can be grouped into three parts: a. Teaching activities in the sense of transfer of knowledge from adults (teachers) to people who are not yet adults (students). Through this teaching activity can be produced by people who have knowledge and broad views, which can then be used as a basis for consideration in formulating various policies that will be taken. This activity can be represented by the words al-Talim, al-Tadris, alTaaqqul, and al-Tafaquh.b. Activities that are educational in nature (education), namely stimulating, exploring, directing, fostering, and forming mental attitudes and personalities that are based on noble and noble values, such as forming an attitude of honesty, perseverance, hard work, patience, independence, and others The educational process is not as easy as the teaching process, but the educational process not only requires teacher knowledge about teaching materials, but must have a personalized educational program. This activity can be represented by the terms al-Tarbiyah, al-tazkiyah, aldzikir, and al-mauidzah.c. Research activities that rely not only on teachers

\footnotetext{
43 Al-Raghib al-Ashafahaniy,..., h. 564.
} 
but also on students. This research activity is related to learning activities which in essence are encouraging and directing students to explore all their potentials and talents, so that all their potentials can be optimally empowered which leads to the birth of superior and confident students. These activities can represented by the terms al-intidzar, altafakkur, and others. ${ }^{44}$

\section{The Implications Of Education For Educator}

Educators are people who have knowledge and do or provide education to others in need. In the Indonesian General Dictionary, educators mean people who educate. ${ }^{45}$ In other opinion, educators are adults who are responsible for giving guidance or assistance to students in their physical and spiritual development in order to reach maturity, able to carry out their duties as God's creatures, caliphs on the surface of the earth, as social beings and as individuals who are capable of standing alone. ${ }^{46}$ Educators can also mean people who are responsible for the development and maturity of the spiritual and physical aspects of children. ${ }^{47}$ According to Ahmad Tafsir, that educators in Islam are people who are responsible for the development of students with effort.

Based on various educators' understanding above, the educator can be interpreted as a person who is responsible for the child's development from the affective, cognitive, psychomotor and spiritual development. carry out the commands of Allah Almighty, for the service of the nation and religion.

The nature of the educator as a human being who understands science is of course and becomes an obligation for him to transfer that knowledge to others for the benefit of the Ummah. The nature of educators is emphasized in the Qur'an AlAlaq (96) verses 1-5 which means:

Read in the name of your Lord who created. He has created mankind from a clot of blood. Read, and your Lord is the most gracious. Who teaches (human) by the delivery of kalam. He taught humans what he did not know.

In the Qur'an the nature of the teacher is Allah SWT, but that does not mean that humans in this world do not have the task of caliph on this earth, one of which is the task of humans to teach the knowledge that has been obtained to others, in other words he as a teacher. ${ }^{48}$

Based on the meaning of education in the Qur'an, an educator should ideally have the abilities and characteristics as depicted in Figure 1. below:

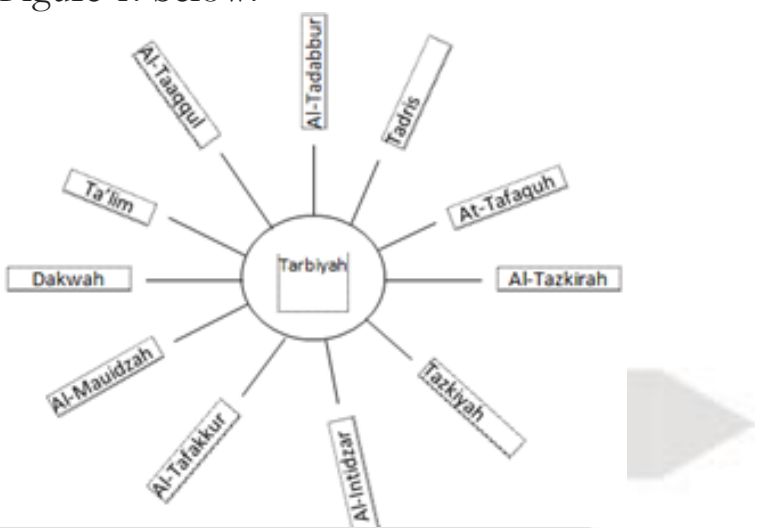

Figure 1. Ideal traits that educators must have $^{49}$

With the ideal qualities possessed by educators such as in the picture above, there will be a process of transfer of good knowledge and in accordance with the teachings of the Al-Quran to humanity. So that these ideal traits can grow and develop in accordance with the values of Islamic education.

\section{Conclusion}

44 Abuddin Nata,..., h. 120-121.

45 W.J.S. Poerwadarminta,..., h. 250

46 Ihsan, dkk,Filsafat Pendidikan

Islam.(Bandung :CV Pustaka Setia, 1998), h. 78.

47 Ramayulis dan Syamsul Nizar.Filsafat

Pendidikan Islam: Telaah Sistem Pendidikan dan Pemikiran

Para Tokohnya. (Jakarta: Kalam Mulia,2010), h.139.
48 Zuhdi, Profil Guru dalam Pendidikan Islam Menurut K.H. Hasyim Asy'ari : Telaah Kitab Adab alAlim wa al-Muta'allim, (Yogyakarta: Tesis Program Pascasarjana UIN Sunan Kalijaga, 2004), h. 19.

49 Tim Penulis Artikel. 
The meaning of education in Islamic Education such as tarbiyah, da'wah, talm, tazkiyah, al-tadris, al-tafaqquh, al-taaqqul, altadabbur, al-tazkirah, altafakkur, al-intidzar, and al-mauizah, are terma terms which are used in Islamic education all of which have implications for the development of Islamic education. Where the overall meaning can be grouped in three parts: a. Teaching activities in the sense of transfer of knowledge from adults (teachers) to people who are not yet adults (students). b. Activities that are educational in nature (education), namely stimulating, exploring, directing, fostering, and forming mental attitudes and personalities that are based on noble and noble values, such as forming an attitude of honesty, perseverance, hard work, patience, independence, and others . c. Research activities that rely not only on teachers but also on students.

Implications of Islamic Education for educators is that educators should possess and instill good qualities in themselves and their personalities. The ideal qualities that educators need to have are tarbiyah, da'wah, talm, tazkiyah, al-tadris, al-tafaqquh, altaaqqul, al-tadabbur, al-tazkirah, altafakkur, al-intidzar, and al-mauizah which are terms the term stated in the Al-Quran.

\section{References \\ Book \\ Abudin Nata, Pendidikean Dalam Prespektif Al- quran, (Jakarta: UIN Jakarta Press, 2005) \\ Abuddin Nata, Kapita Selekta Pendidikan Islam, Isu-isu Kontemporer Pendidikan Islam, (Jakarta: Rajawali Pers, 2012) \\ Ab Abdillh Muhammad bin Ahmad al-Anr al-Qurthub, Al-Jmi li-Abkmi al-Qurn, Jilid I (t.d) \\ Ahmad Musthafa Al-Maraghiy, Tafsir Al- Maraghiy, juz XXVIII, (Semarang: CV Toha Putra, 1989) \\ Ahmad Tafsir, Ilmu Pendidikan dalam Perspektif Islam, (Bandung: Rosda Karya, 1992)}

Al-Raghib al-Ashafahaniy, Mujam Murfadat Alfadz, al-Quran, (Beirut: Dar al-Fikr, t.t.)

Jalaluddin, Teologi Pendidikan, (Jakarta: PT. RajaGrafindo Persada, 2003)

Kadar M. Yusuf, Tafsir Tarbawi: Pesan-Pesan Al-Qur-an tentang Pendidikan,Cet-ke-I, (Jakarta: Amzah, 2013)

Louis Maluf, Al-Munjid fi al-Lughah wa alAlam.Cet. XXVII, (Beirut: Dr alMasyriq, 1984)

Muhaimin, Nuansa Baru Pendidikan Islam; Mengurai Benang Kusut Dunia Pendidikan, (Jakarta: PT. RajaGrafindo Persada, 2006)'

Muahaimin, Rekonstruksi Pendidikan Islam : Dari paradigma Pengembangan, Manjemen Kelembagaan, Kurikulum hingga Strategi Pembelajaran, (Jakarta: PT. RajaGrafiondo Persada, 2009)

M. Arifin, Ilmu Pendidikan Islam Suatu Tinjauan Teoritis Dan Praktis BerdasarkanPendekatan Interdisipliner, (Jakarta: Bumi Aksara, 1991)

M. Arifin, Ilmu Pendidikan Islam, Jakarta: Bumi Aksara, 1991)

W.J.S. Poerwadarminta, Kamus Umum Bahasa Indonesia, (Jakarta: Balai Pustaka, 1991)

Zakiyah Daradjat, dkk., Ilmu Pendidikan Islam, (Jakarta: Bumi Aksara, 1996)

Zuhairini, dkk., Filsafat Pendidikan Islam, (Jakarta: Bumi Aksara, 1995).

Ramayulis dan Syamsul Nizar, Filsafat Pendidikan Islam: Telaah Sistem Pendidikan dan Pemikiran Para Tokohnya, Jakarta: Kalam Mulia, 2010)

Samsul Nizar, Pengantar Dasar-Dasar Pemikiran Pendidikan Islam, (Jakarta: Gaya Media Pratama, 2001)

Ihsan, dkk, Filsafat Pendidikan Islam, (Bandung : CV Pustaka Setia, 1998)'

\section{Journal}

Ahmad Zuhdi, Profil Guru dalam Pendidikan Islam Menurut K.H. Hasyim Asy'ari : Telaab Kitab Adab al-Alim wa alMuta'allim, Tesis Program Pascasarjana UIN Sunan Kalijaga 2004, (tidak diterbitkan) 
Alfurqan dan Harmonedi, Pandangan Islam Terbadap Manusia : Terminologi Manusia dan Konsep Fitrah serta Implikasinya dengan Pendidikan. JURNAL EDUCATIVE: Journal of Educational Studies Vol 2, No 2, Juli - Desember 2017, DOI : $10.30983 /$ educative.v2i2.468

)

Basyar, Syaripudin, PENDIDIKAN ISLAM DI ERA GLOBALISASI: Antara Konsepsi Dan Aplikasi, $A L$ IDARAH: JURNAL KEPENDIDIKAN ISLAM, 2018:doi.org/10.24042/alidarah.v8i1. 3075

Isnaniah, and M. Imamuddin, 'Students' Understanding of Mathematical Concepts Using Manipulative Learning Media in Elementary Schools', $1^{\text {st }}$ Bukittinggi International Conference on Education, IOP Conf. Series: Journal of Physics: Conf. Series 1471 (2020) 012050, Doi: $\quad 10.1088 / 1742-$ 6596/1471/1/012050

Iswantir M., Gagasan dan Pemikiran Serta Praksis Pendidikan Islam di Indonesia (Studi Pemikiran dan praksis Pendidikan Islam Menurut Azyumardi Azra). JURNAL EDUCATIVE: Journal of Educational Studies Vol 2, No 2, Juli - Desember 2017,DOI $: 10.30983 /$ educative.v2i2.471

Mafidin, Studi Literatur Tentang Peran Mubammadiyah Dalam Mengembangkan Pendidikan Islam Di Indonesia, Jurnal Tarbawi, 1.1 (2012), 43-53

Mahmud Yunus, Kamus Arab-Indonesia, (Jakarta: Hidakarya, 1990)

Maragustam, Mencetak Pembelajar Menjadi Insan Paripurna, (Yokyakarta: Nuha Litera, 2010)

M. Imamuddin, dkk., Integrasi Pendidikan Islam dan Pendidikan Matematika Dalam Pembelajaran. NUR EL- ISLAM: Jurnal Pendidikan dan Sosial Keagamaan, Vol 6, No 1 (2020) April 2020

Moh. Haitami Salim \& Syamsul kurniawan, Studi Ilmu Pendidikan Islam, Jakarta: Ar-Ruzz Media, 2012)

Nunu Burhanuddin, Konstruksi Pendidikan
Integratif Menurut Hamka, JURNAL EDUCATIVE: Journal of Educational Studies Vo.1, No.1, Januari - Juni 2016, DOI : 10.30983/educative.v1i1.119

Nuryatno, M. Agus, Islamic Education in a Pluralistic Society', Al-Jami'ah: Journal of Islamic Studies, 2011: doi.org/10.14421/ajis.2011.492.411431

Sukring, Pendidik Dalam Pengembangan Kecerdasan Peserta Didik (Analisis Perspektif Pendidikan Islam).Tadris: Jurnal Keguruan dan Ilmu Tarbiyah 01 (1) (2016), Juni 2016, h. 69-80 